Original Article

\title{
ISOLATION AND CHARACTERISATION OF ANTI-BACTERIAL RESISTANCE PATTERNS OF BACTERIAL ISOLATES FROM URINARY TRACT INFECTION IN DIABETICS
}

\author{
HARIKRISHNAN S. ${ }^{*}$, ROSY VENNILA, R. MONICA \\ ${ }^{*}$ Department of Microbiology, Saveetha Medical College, Chennai 602105 \\ Email: vlrharikrishnan@gmail.com
}

Received: 20 Sep 2020, Revised and Accepted: 17 Nov 2020

\section{ABSTRACT}

Objective: Urinary tract infection (UTI) is one of the most common infections observed in diabetic patients. This study is aimed at identifying the organisms with their anti-bacterial resistance pattern.

Methods: A total of 400 diabetic patients over a period of nine months presenting with symptom s of urinary tract infection were taken for the study. Their urine were cultured and an antibiogram done.

Results: E. coli, Klebsiella and Enterococci were the commonest organism found. It was found that E. coli, which was the commonest organism E. Coli was sensitive to Norfloxacin and resistant to Ciprofloxacin.

Conclusion: Empirical treatment with ciprofloxacin, Which is considered the drug of choice, will lead to failure of treatment.

Keywords: Anti-bacterial, Bacterial, Isolates, Urinary tract

(C) 2021 The Authors. Published by Innovare Academic Sciences Pvt Ltd. This is an open access article under the CC BY license (https://creativecommons.org/licenses/by/4.0/) DOI: https://dx.doi.org/10.22159/ijcpr.2021v13i1.40816. Journal homepage: https://innovareacademics.in/journals/index.php/ijcpr

\section{INTRODUCTION}

Diabetes mellitus (DM) has a number of effects on genitourinary system. Patients with diabetes mellitus are at increased risk for urinary tract infection [1]. Urinary Tract Infection (UTI) is more common in diabetics because of a combination of host and local risk factors [2]. Under some circumstances urine may be inhibitory or even bactericidal against uro-pathogens. Modification of chemical composition of urine in diabetes mellitus can alter the ability of urine and support the growth of microorganisms. Autonomic neuropathy in diabetes mellitus impairs bladder emptying and subsequent urological manipulation pre-dispose to UTI [3].

Escherichia are the most common bacterial pathogen causing urinary infection in patients with diabetes, the other two most common being Klebsiella and Enterococcus species [4]. Therefore this study has been undertaken to assess the prevalence of urinary tract infection, the most common causative pathogens and their resistance pattern in diabetic patients.

\section{MATERIALS AND METHODS}

A total of 400 diabetic patients who presented with suspected UTI were studied for a period of nine months (From March 2020 to November 2020). The symptoms that lead to the suspicion of UTI include-Fever, dysuria, urinary incontinence, supra-pubic pain frequency and urgency if urination. Diagnosis of diabetes was made based on the WHO criteria [5]. Clean voided midstream urine samples were collected in sterile containers after giving proper instructions and samples were processed in the laboratory within 2 $\mathrm{h}$ of collection. Urine cultures were done by inoculating urine samples on blood agar plates using a calibrated loop $(0.001 \mathrm{ml})$ and incubated at 37 degrees Celsius for 18-24 h. The culture reports were considered positive when they had colony-forming units more than $105 / \mathrm{ml}$ of voided urine. The pathogens were isolated and biochemical tests were done for identifying the species of the pathogens. Antimicrobial sensitivity was done by the Kirby-Bauer disc diffusion method.

\section{RESULTS}

Four hundred Diabetic patients with symptoms of urinary tract infections were screened during this period. During this period, the most common microorganism isolated, tabulated in table 1, includes Escherichia Coli, Klebsiella Pneumoniae and Enterococcus. The other microorganisms that were infrequently isolated from the urine culture samples were Acinetobacter, Pseudomonas, Enterobacter, Citrobacter, Staphylococcus, Candidia, Streptococcus, Proteus, Serratia.

Table 2 shows the resistance pattern of the common organisms isolated. The Escherechia Coli isolates obtained were found to be having maximum resistance to Ciprofloxacin (92\%), Cefuroxime (83\%) and Ampicillin (97\%). Least resistance was seen in Amikacin, Ertapenem and Norfloxacin. These are shown in table 3.

Table 1: Major bacteria isolated

\begin{tabular}{ll}
\hline Bacteria Isolated & Percentage (\%) \\
\hline Escherechia coli & 48.75 \\
Klebsiella pneumoniae & 14 \\
Enterococcus & 11.75 \\
\hline
\end{tabular}

Table 2: Resistant patterns of most common bacterial isolates from UTI in diabetics

\begin{tabular}{|c|c|c|c|c|c|c|c|c|c|c|c|}
\hline & Amp & Amk & Azm & $\mathrm{Cfz}$ & Cip & Col & Cxm & Etp & Gen & Nor & Ofx \\
\hline E. Coli & 97 & 4 & NA & 65 & 92 & 68 & 83 & 9 & 50 & 9 & 69 \\
\hline Klebsiella & 100 & 75 & NA & 55 & 63 & 25 & 61 & 10 & 38 & 53 & 33 \\
\hline Enterococcus & 67 & NA & NA & 5 & 100 & NA & NA & 100 & NA & 100 & 100 \\
\hline
\end{tabular}


Table 3: Sensitivity pattern of E Coli

\begin{tabular}{|c|c|c|}
\hline E. Coli & Sensitive & Resistant \\
\hline Ampicillin & 3 & 97 \\
\hline Amikacin & 96 & 4 \\
\hline Azithromycin & NA & NA \\
\hline Cefazolin & 35 & 65 \\
\hline Ciprofloxacin & 8 & 92 \\
\hline Colistin & 32 & 68 \\
\hline Cefuroxime & 17 & 83 \\
\hline Ertapenem & 91 & 9 \\
\hline Gentamycin & 50 & 50 \\
\hline Norfloxacin & 91 & 9 \\
\hline Ofloxacin & 31 & 69 \\
\hline
\end{tabular}

In the case of Klebsiella Pneumoniae, as shown in table 4, increased resistance was seen towards Ampicillin (100\%) followed by
Amikacin (75\%). Least resistance was seen towards Ertapenem $(10 \%)$.

Table 4: Sensitivity pattern of Klebsiella

\begin{tabular}{|c|c|c|}
\hline Klebsiella & Sensitive & Resistant \\
\hline Ampicillin & 0 & 100 \\
\hline Amikacin & 25 & 75 \\
\hline Azithromycin & NA & NA \\
\hline Cefazolin & 45 & 55 \\
\hline Ciprofloxacin & 37 & 63 \\
\hline Colistin & 75 & 25 \\
\hline Cefuroxime & 39 & 61 \\
\hline Ertapenem & 90 & 10 \\
\hline Gentamycin & 62 & 38 \\
\hline Norfloxacin & 47 & 53 \\
\hline Ofloxacin & 67 & 33 \\
\hline
\end{tabular}

In the case of Enterococcus, increased resistance towards Ciprofloxacin (100\%) and least resistance were seen to Cefazolin (5\%). This is shown in table 5 .

Table 5: Sensitivity pattern Enterococcus

\begin{tabular}{lll}
\hline Enterococcus & Sensitive & Resistant \\
\hline Ampicillin & 33 & 67 \\
Amikacin & NA & NA \\
Azithromycin & NA NA & 5 \\
Cefazolin & 95 & 100 \\
Ciprofloxacin & 0 & NA \\
Colistin & NA & NA \\
Cefuroxime & NA & 100 \\
Ertapenem & 0 & NA \\
Gentamycin & NA & 100 \\
Norfloxacin & 0 & 100 \\
Ofloxacin & 0 & \\
\hline
\end{tabular}

\section{DISCUSSION}

In our study it was found that gram-negative bacilli $(75 \%)$ were the most common organisms for urinary tract infections in diabetics. Of this approximately $50 \%$ were E. Coli. Among the Gram positive bacterias isolated, around $70 \%$ of them were Enterococcus [6].

In clinical settings, Ciprofloxacin, is used as empiric treatment for urinary tract infection. In our study, it was found that E. Coli which is the most common organism that causes UTI, was resistant to Ciprofloxacin in $92 \%$ of the isolates. Ironically, Norfloxacin, which belongs to an older generation of Quinolone, eradicated $91 \%$ of the E. Coli. This may be due to the more common use of Ciprofloxacin in the current era of treating Urinary Tract Infections [7]. The above situation is similar to Typhoid bacteria. In 1970s, Chloramphenicol was the drug of choice for Typhoid fever. Subsequently, the bacteria developed resistance to Chloramphenicol and Ciprofloxacin was used as the empiric choice for treating Typhoid fever. In the last few years, the bacteria has become resistant to Ciprofloxacin and has become sensitive to Chloramphenicol again [8-10].
The above information can be clinically applied to treat urinary tract infection by choosing Norfloxacin instead of Ciprofloxacin as the primary drug of choice for treating UTI in diabetics.

The second commonest organism isolated in the urine cultures were Klebsiella. Klebsiela was sensitive to $2 / 3^{\text {rd }}$ of the patients to Ofloxacin. It was resistant to most of the patients to Cirpofloxacin as well as Norfloxacin. So Ofloxacin given orally will be effective in most of the patients in treating Klebsiella.

While, Amikacin which is one of the commonest aminioglycosides used in the parental treatment of Klebsiella urinary tract infections, was found to be resistant. While Ertapenem, which is a newer Monobactam was found to be sensitive to $90 \%$ of the patients. Hence Urosepsis due to Klebsiella, Ofloxacin will be the choice of oral treatment, while in more severe cases, parental treatment will Ertapenem will be the ideal drug of choice.

Enterococcus species caused most of the gram-positive urinary tract infection. It is sensitive to $95 \%$ of the isolates to Cefazolin. 
While all the isolates (100\%) were resistant to Ciprofloxacin. Again, this can be due to overuse of this quinolone causing resistant species of bacteria. Hence when gram-positive treatment is considered in Urosepsis, Cefazolin should be the empirical drug of choice.

\section{CONCLUSION}

In conclusion, Gram-negative bacterias were highly sensitive to Norfloxacin and Ofloxacin, and Gram-Positive bacterias were more susceptible to Cefazolins in the case of a Urinary Tract Infection of diabetic patients. Since there are new emerging patterns of resistance seen in patients with Diabetics with UTIs, it is recommended that continued surveillance of resistance rates is needed to ensure appropriate treatment of these infections.

\section{FUNDING}

Nil

\section{AUTHORS CONTRIBUTIONS}

All the authors have contributed equally.

\section{CONFLICT OF INTERESTS}

Declared none

\section{REFERENCES}

1. Muller LMA J, Gorter KJ, Hak E, Goudzwaard WL, Schellevis FG, Hoepelman AIM, et al. Increased risk of common infections in patients with type 1 and type 2 diabetes mellitus. Clin Infect Dis 2005;3:281-8.
2. Adeyeba, PO Omosigho, YO Adesiji. Bacterial urinary tract infections in patients with diabetes mellitus. Int J Trop Med 2007;2:89-2.

3. Goswami R, Bal CS, Tejaswi S, Punjabi GV, Kapil A, Kochupillai N. Prevalence of urinary tract infection and renal scars in patients with diabetes mellitus. Diab Res Clin Pract 2001;53:181-6.

4. Lloyds S, Zervas M, Mahayni R, Lundstrom T. Risk factors for enterococal urinary tract infection and colonization in a rehabilitation facility. Am J Infect Control 1998;26:35-9.

5. World Health Organization: Definition, Diagnosis and Classification of diabetes mellitus and its complications; Part 1: Diagnosis and Classification of diabetes mellitus, Geneva. Department of non communicable Disease Surveillance. WHO; 1999.

6. Bonadio M, Costarelli S, Morelli G, Tartaglia T. The influence of diabetes mellitus on the spectrum of uropathogens and the antimicrobial resistance in elderly adult patients with urinary tract infection. BMC Infect Dis 2006;6:54.

7. Bashir MF, JI Qazi, N Ahmed, S Riaz. Diversity of urinary tract pathogens and drug-resistant isolates of Escherichea coli in different age and gender groups of Pakistanis. Trop J Pharm Res 2008;7:1025-31.

8. Bhatia JK, Mathur AD, Arora MM. Reemergence of chloramphenicol sensitivity in enteric fever. Med J Armed Forces India 2007;63:212-4.

9. Bauer AW, Kirby WMM, Sherris JC, Turck M. Antibiotic susceptibility testing by a standardised singles disk method. Am J Clin Pathol 1966;45:493-6.

10. Akhtar S, Sarker MR, Jabeen K, Sattar A, Qamar A, Fasih N Antimicrobial resistance in Salmonella enterica serovar typhi and paratyphi in South Asia-current status, issues and prospects. Crit Rev Microbiol 2015;41:536-45. 